\title{
Srategi Membangun Karakter Kewirausahaan Pada Anak Usia PAUD-SD di Lereng Gunung Merapi (Dusun Tunggul Arum, Wonokerto - Turi)
}

\author{
Tatik $^{1}$, Khoirina Noor Anindya ${ }^{2}$ \\ Fakultas Ekonomi - Universitas Islam Indonesia \\ email:162121302@uii.ac.id
}

\begin{abstract}
ABSTRAK
Anak-anak merupakan investasi terbesar orang tua, baik untuk dunia maupun akhirat. Mereka juga merupakan generasi penerus bangsa. Di pundak mereka kelak, harapan kemajuan dan masa depan bangsa dititipkan. Pendidikan anak sudah selayaknya mendapatkan perhatian lebih besar agar mereka memiliki keunggulan dan prestasi yang membanggakan. Pendidikan ini tidak hanya terbatas pada pendidikan formal semata, melainkan juga menekankan pada pendidikan karakter yang menjadi pondasi bagi tumbuh kembang anak.

Idealnya menumbuhkan dan mengarahkan anak agar memiliki karakter kewirausahaaan dimulai sejak usia dini. Karena masa anak-anak merupakan fase yang paling subur, paling panjang dan paling dominan untuk menanamkan norma-norma yang mapan, dengan potensi fitrah yang bersih, kepolosan yang jernih, kelembutan dan kelenturan jasmani, kalbu yang belum tercemari, dan jiwa yang belum terkontaminasi (Jamaal Abdur Rohman, 2005:22).

Pengabdian ini bertujuan untuk menumbuhkan karakter kewirausahaan pada anak di Dusun Tunggul Arum, Desa Wonokerto, Turi-Sleman. Metode yang digunakan dalam pengabdian ini adalah pelatihan dan pendampingan. Pelatihan dilakukan dua kali, yang pertama ditujukan untuk anak-anak dan yang ke-dua untuk orang tua. Setelah pelatihan, anak-anak mendapatkan pendampingan berkelanjutan yang dilakukan oleh tokoh masyarakat setempat.
\end{abstract}

Kata kunci: anak, karakter kewirausahaan, pendampingan, strategi

\section{ABSTRACT}

Children are the biggest investment of parents, both for the world and the hereafter. They are also the next generation of the nation. On their shoulders, hopes for the progress and future of the nation are entrusted. Children's education should get more attention so that they have superior and proud achievements. This education is not only limited to formal education, but also emphasizes character education which is the foundation for children's growth and development.

Ideally growing and directing children to have an entrepreneurial character starting from an early age. Because childhood is the most fertile, longest and most dominant phase for inculcating established norms, with the potential for clean nature, clear innocence, tenderness and physical flexibility, an uncontaminated heart, and an uncontaminated soul (Jamaal Abdur Rohman, 2005: 22).

This service aims to foster the entrepreneurial character of children in Tunggul Arum Hamlet, Wonokerto Village, Turi-Sleman. The method used in this service is training and mentoring. The training is done twice, the first is intended for children and the second is for parents. After the training, the children get ongoing assistance provided by local community leaders.

Keywords: entrepreneurial character, children, mentoring, strategy 


\section{PENDAHULUAN}

Dusun Tunggul Arum, Wonokerto-Turi berada di lereng teratas sebelah barat gunung Merapi. Lokasinya terletak sekitar 30 kilometer dari pusat Kota Yogykarta. Dusun ini berjarak sekitar 8 kilometer dari puncak Merapi dan 8 kilometer dari kampus terpadu Universitas Islam Indonesia. Dusun Tunggul Arum dekat dengan Sungai Krasak yang merupakan aliran lahar dari erupsi Gunung Merapi.

Berdasarkan data hasil Survey Pamsimas (Program Penyediaan Air Minum dan Sanitasi Berbasis Masyarakat) tahun 2017, Dusun Tunggul Arum sangat kaya akan potensi alam. Potensi alam di Dusun Tunggul Arum antara lain bidang perkebunan salak, cabai dan padi. Potensi lainnya yaitu di bidang peternakan, baik ternak sapi perah, sapi penggemukan/pedaging maupun ternak kambing. Dalam bidang perairan, Tunggul Arum merupakan daerah tanggapan air yang berasal dari sumber air Merapi, warga memanfaatkannya sebagai sumber air minum dan kolam ikan rumahan. Dalam bidang pertambangan, Tunggul Arum memiliki potensi tambang galian c dengan hasil tambang pasir dan bebatuan dari erupsi Merapi. Pemandangan alam yang indah, dilengkapi dengan hutan rakyat, bunker perlindungan dari erupsi Merapi, gardu pandang, Goa Semar, dan kirab Merti Bumi di bulan Sapar kalender Jawa, menjadikan Tunggul Arum memiliki potensi sebagai Desa Wisata.

Potensi alam yang sangat kaya di Tunggul Arum ternyata tidak sebanding dengan pendapatan warga. Masih berdasarkan data hasil Survey Pamsimas tahun 2017, penghasilan ratarata warga Tunggul Arum berkisar antara Rp 1.000.000-Rp 1.500.000 per bulan. Warga Tunggul Arum berprofesi sebagai petani, peternak dan penambang batu. Hanya ada 2 orang yang berprofesi sebagai Pegawa Negeri Sipil (PNS).

Data Survey Pamsimas juga mencatat di Dusun Tunggul Arum terdapat $163 \mathrm{KK}$ dan 605 cacah jiwa. Dari jumlah 605 jiwa, tercatat warga yang menempuh pendidikan Paud-TK sebanyak 53 anak, SD 38 anak, SMP 20 orang, SMA 15 orang, Perguruan Tinggi 2 orang, dan sisanya sekitar 476 orang tidak sekolah.

Rendahnya tingkat pendidikan berdampak pada terbatasnya akses pekerjaan yang layak sehingga pendapatan warga Tunggul Arum juga relatif kecil. Tidak hanya kebutuhan hidup seharihari yang kekurangan, biaya pendidikan pun juga kekurangan. Hal tersebut berdampak ulang pada terbatasnya akses pendidikan bagi anak-anak di Dusun Tunggul Arum. Rata-rata anak di Dusun Tunggul Arum hanya menyelesaikan sampai jenjang Sekolah Dasar (SD). Setelah lulus SD, mereka membantu orang tua bertani di ladang maupun menjadi penambang pasir. Sebagian lagi memutuskan menikah dini karena tidak memiliki akses dan motivasi untuk melanjutkan sekolah maupun kegiatan lain untuk masa depannya. Bagi anak-anak di Tunggul Arum, menyelesaikan 
pendidikan hingga SD lalu bekerja sebagai petani atau penambang pasir adalah pilihan hidup yang harus dijalani, sama seperti nasib orang tua, keluarga maupun teman-teman seusianya.

Pola asuh orang tua dengan keterbatasn pendidikan dan budaya masyarakat sekitar, membentuk karakter anak di lereng Merapi ini cenderung tidak percaya diri, motivasi yang rendah untuk belajar, budaya instan, dan tidak memiliki kreativitas dalam menjalani aktivitas sehari-hari. Karakter tersebut sangat bertolak belakang dengan karakter kewirausaan yang sebaiknya dikembangkan pada anak-anak. Buchari Alma (2010) menyatakan bahwa ada tujuh karakter kewirausahaan, pertama percaya diri, kedua berorientasi pada tugas dan hasil, ketiga pengambilan risiko, keempat kepemimpinan, kelima keorisinalan, keenam berorientasi masa depan dan ketujuh kreativitas.

Idealnya menumbuhkan dan mengarahkan anak agar memiliki karakter kewirausahaaan dimulai sejak usia dini. Karena masa anak-anak merupakan fase yang paling subur, paling panjang dan paling dominan untuk menanamkan norma-norma yang mapan, dengan potensi fitrah yang bersih, kepolosan yang jernih, kelembutan dan kelenturan jasmani, kalbu yang belum tercemari, dan jiwa yang belum terkontaminasi (Jamaal Abdur Rohman, 2005:22).

Berdasarkan uraian di atas, kami melakukan pendampingan untuk membangun karakter anakanak di Dusun Tunggul Arum melalui kegiatan pengabdian masyarakat dengan pendekatan kepada orang tua dan anak.

\section{METODE KEGIATAN}

Metode kegiatan yang dilaksanakan dalam pengabdian ini adalah diskusi parenting dengan orang tua, training motivasi untuk anak-anak dan pendampingan pasca training untuk anak-anak.

Adapun gambaran tiap kegiatan sebagai berikut:

1. Training Motivasi untuk Anak-Anak

Training motivasi untuk anak-anak dilaksanakan pada tanggal 19 Agustus 2018 di rumah Bapak Sugito, salah satu tokoh masyarakat di Dusun Tunggul Arum. Kegiatan dilaksanakan mulai pukul 09.00 - 12.00. Setelah kegiatan training motivasi untuk anak-anak akan dilanjutkan dengan diskusi parenting untuk orang tua pada hari yang sama.

Training diawali dengan ice breaking dan games untuk mencairkan suasana sekaligus membangun kedekatan trainer dengan anak-anak agar pesan-pesan yang disampaikan ketika training dapat diterima dengan baik.

Anak-anak sangat antusias mengikuti games bersama para trainer. Tawa ceria mengiringi rangkaian kegiatan training motivasi. Trainer juga menyediakan doorprize untuk para peserta yang diumumkan diawal kegaiatan sehingga menambah antusias anak-anak mengikuti acara. 
Games dirancang dengan berbagai permainan untuk membangun rasa percaya diri, kekompakan kelompok dan motivasi untuk menang/berprestasi sesuai dengan analisis permasalahan disana.

Kegiatan dilanjutkan dengan training motivasi. Training motivasi didesain menarik untuk anak-anak dengan menyuguhkan film agar anak-anak tidak jenuh jika terlalu lama mendengarkan penjelasan. Film tersebut menceritakan perjuangan seorang anak desa dari keluarga tidak mampu untuk melanjutkan sekolah dan mengejar cita-citanya. Dalam film tersebut juga dikisahkan orang tua sangat mendukung cita-cita anaknya dan memberikan motivasi.

Pada akhir acara, trainer mereview cerita dalam film dan mendiskusikannya dengan anakanak. Anak-anak bersahutan menjelaskan isi cerita dalam film dan trainer menyimpulkan sekaligus memotivasi anak-anak untuk memiliki semangat berprestasi seperti tokoh dalam film tersebut.

2. Diskusi Parenting

Kegiatan diskusi parenting dilaksanakan pada tanggal 19 Agustus 2018 di rumah Bapak Sugito, salah satu tokoh masyarakat di Dusun Tunggul Arum. Kegiatan dilaksanakan mulai pukul $13.00-15.00$.

Setelah anak-anak mengikuti training motivasi untuk berprestasi, orang tua mereka juga dibekali dengan diskusi parenting agar tercipta kesamaan persepsi antara anak dan orang tua untuk menggapai kesuksesan bersama.

Diskusi dimulai dengan pembukaan oleh MC dan dilanjutkan dengan sambutan dari Bapak Sugito. Dalam sambutannya, tokoh masyarakat Tunggul Arum tersebut menyampaikan terima kasih kepada pihak Universitas Islam Indonesia yang telah berkenan melaksanakan pengabdian di Dusun Tunggul Arum dengan mengadakan acara parenting dan pendampingan kepada anakanak. Bapak Sugito berpesan agar para peserta diskusi parenting menyerap ilmu dan pengalaman sebanyak-banyaknya yang akan disampaikan oleh narasumber, Dr. phil. Qurrotul Uyun, S. Psi, M. Si, Psikolog, sebagai pakar psikologi dan parenting.

Acara dilanjutkan dengan diskusi parenting dengan narasumber Dr. phil. Qurrotul Uyun, S. Psi, M. Si, Psikolog. Beliau memulai acara dengan mendiskusikan harapan peserta terhadap acara parenting tersebut. kemudian mengajak peserta berdiskusi kembali tentang harapan orang tua terhadap anak. Dr. phil. Qurrotul Uyun, S. Psi, M. Si, Psikolog juga sharing pengalaman pribadi sebagai seorang anak dari keluarga sederhana dan banyak saudara, namun orang tua beliau memiliki motivasi yang kuat agar anak-anaknya bisa memperoleh pendidikan setinggi-tingginya.

Pada acara diskusi parenting tersebut disampaikan tentang tujuan pendidikan tinggi, tips orang tua dalam mendidik anak, tantangan dan peluang dalam pendidikan anak.

3. Pendampingan Pasca Training 
Pengabdi berdiskusi dengan tokoh masyarakat untuk tindak lanjut kegiatan pengabdian, agar kegiatan tidak berhenti setelah pelatihan saja. Tokoh masyarakat setempat telah memiliki rancangan kegiatan berupa pendampingan berkelanjutan untuk anak-anak.

Pendampingan berupa pertemuan rutin pekanan yang diselenggarakan di rumah Bapak Sugito merupakan partisipasi dari mitra kegiatan pengabdian. Pertemuan tersebut dibersamai Ibu Lilis, istri Bapak Sugito dan beberapa Ibu-Ibu muda. Dalam pertemuan tersebut diberikan pemahaman keislaman bagi anak-anak, sharing dan pembahasan PR (Pekerjaan Rumah) maupun pengulasan mata pelajaran di sekolah yang diperlukan.

Orang tua tidak dipungut biaya sama sekali untuk penyelenggaraan pendampingan anak tersebut. Kegiatan tersebut murni sebagai kegiatan sosial yang merupakan wujud kepedulian tokoh masyarakat yang peduli akan pendidikan dan masa depan anak di Dusun Tunggul Arum, Wonokerto, Turi.

\section{HASIL DAN PEMBAHASAN}

Kewirausahaan merupakan suatu bentuk karakter yang perlu dibangun sejak usia dini. Nilainilai yang perlu diimplementasikan melalui karakter tersebut adalah nilai-nilai kreativitas, inovasi, keberanian, kemandirian, dan tanggungjawab (Antawati, Dewi Ilma).

Kegiatan pengabdian ini dirancang untuk menumbuhkan karakter kewirausahaan pada anak melalui beberapa kegiatan yang melibatkan anak secara langsung, orang tua dan lingkungan sekitar.

Pada kegiatan training motivasi, anak diberikan motivasi untuk berprestasi dan memiliki karakter-karakter kewirausahaan. Kegiatan ini tentu disesuaikan dengan fitroh anak yang suka dengan permainan. Diharapkan dari training tersebut anak-anak terdorong untuk menggali potensinya dan mengukir prestasi.

Dalam proses pembentukan karakter kewirausahaan pada anak, peran orangtua sangatlah besar. Peran orang tua tersebut bermula dari harapan orang tua terhadap perkembangan anakanaknya. Ada orang tua yang berharap anaknya sukses dengan karir dunia. Ada juga orang tua yang berharap anaknya memperoleh kesuksesan dunia dan akhirat. Kedua harapan yang berbeda itu tentu akan mengarahkan pola asuh yang berbeda juga terhadap anak.

Beberapa hal yang dapat dilakukan orang tua dalam menumbuhkan kesuksesan anak antara lain:

1. Menunaikan hak anak

Orang tua berkewajiban menunaikan hak-hak terhadap anaknya, antara lain memenuhi kebutuhan primernya (pangan, sandang, papan), pengasuhan yang baik dan pendidikan yang layak.

2. Kesabaran 
JAMALI - Volume. 01, Issue. 02, September 2019

Kesabaran mendampingi anak dapat diperoleh orang tua melalui:
a. Menghargai usaha anak
b. Menjaga komunikasi yang baik
c. Menanamkan kepercayaan dan tanggung jawab kepada anak

3. Memberikan teladan dan instropeksi diri

Anak adalah cerminan orang tua. Jika anak melakukan suatu kesalahan, atau orang tua merasa nasehatnya tidak dipatuhi oleh anak, orang tua perlu melakukan intropeksi, mengevaluasi diri. Mungkin orang tua belum memberikan teladan yang baik pada anak. Jika pun orang tua merasa telah memberikan teladan, orang tua perlu juga mengevaluasi cara dalam mendidik anak.

Kesalahan yang banyak terjadi dalam pendidikan anak, orang tua beranggapan cara mendidik anak-anak zaman sekarang sama seperti cara orang tua mereka mendidik di waktu mereka kecil. Padahal zaman sudah berubah, kemajuan teknologi yang setiap hari menjadi konsumsi anak-anak semakin berkembang. Dibutuhkan pola pendidikan yang disesuaikan dengan perkembangan zaman sekarang.

4. Mendoakan dan banyak istighfar

Doa merupakan senjata ampuh orang tua untuk memohonkan kesuksesan dunia akhirat bagi anak-anaknya. Selain berdoa, orang tua disarankan untuk memperbanyak istighfar agar dilancarkan dan diberi kekuatan untuk mendidik anak.

"Barang siapa membiasakan diri untuk beristighfar, Allah akan memberikan jalan keluar baginya dari setiap kesulitan, akan memberikan kebahagiaan dari setiap kesusahan, dan akan memberikan rezeki dari arah yang tidak disangka-sangka”. (HR Abu Daud dan Ibnu Majah)

5. Tawakal

Manusia hanya bisa berikhtiar, Allah - lah yang menentukan hasil dari ikhtiar itu. Begitu juga dengan pendidikan anak. Orang tua berikhtiar seoptimal mungkin untuk mendidik anak-anaknya, dan menyerahkan hasilnya pada Allah. Jika pun karakter anak belum sesuai dengan harapan orang tua, orang tua tidak perlu berputus asa.

Selain dukungan dari orang tua, juga diperlukan dukungan dari lingkungan sekitar untuk menumbuhkan karakter kewirausahaan pada anak. Lingkungan sekitar menjadi tempat anak menghabiskan waktunya bersama teman-teman seusianya dengan berbagai permainan. Anak sangat mudah meniru dan menyerap informasi dari lingkungan sekitar, apalagi dalam suasana ceria saat bermain bersama.

Peran dunia pendidikan dalam pembentukan karakter anak juga sangat besar. Anak-anak yang berada di jenjang Sekolah Dasar cenderung lebih menuruti nasehat guru. Orang tua perlu memberikan dukungan kepada anak-anak agar lebih bersemangat mengikuti proses pendidikan, jika memungkinkan hingga menempuh pendidikan tinggi. 
Tujuan dari pendidikan tinggi adalah untuk:

a. Menambah pengetahuan

b. Meningkatkan kreativitas

c. Meningkatkan wawasan

d. Memperluas pergaulan

e. Kebermanfaatan ilmu

Anak-anak yang berasal dari keluarga dengan kondisi ekonomi menengah ke bawah, seringkali mengalami tantangan untuk melanjutkan ke jenjang perguruan tinggi karena keterbatasan biaya. Namun, anak-anak yang memiliki daya juang yang tinggi dan didukung orang tua, meskipun mengalami tantangan untuk melanjutkan ke perguruan tinggi, mereka akan gigih mencari solusi, baik dengan jalan mencari beasiswa maupun mencari biaya sekolah dengan bekerja.

Tidak disanksikan, peran orang tua, lingkungan sekitar dan lembaga pendidikan sangat berpengaruh dalam menumbuhkan karakter anak. Ketika anak telah memiliki karakter kewirausahaan, yang tercermin dari kemandirian anak, rasa tanggung jawab, berani, kreatif dan bersemangat meraih cita-cita, diharapkan anak mampu memperoleh kesuksesan masa depan, baik dunia maupun akhirat.

Dalam kegiatan pengabdian ini, kendala yang dihadapi pengabdi adalah kurangnya partisipasi dari orang tua anak pada kegiatan pelatihan. Namun, anak-anak sangat antusias mengikuti acara ini. Tokoh masyarkat pun bersemangat untuk melakukan follou up dengan kegiatan pendampingan secara rutin.

\section{SIMPULAN}

a. Kesimpulan

Karakter kewirausahaan tercermin dari implementasi nilai kreativitas, inovasi, keberanian, kemandirian, dan tanggungjawab. Idealnya menumbuhkan dan mengarahkan anak agar memiliki karakter kewirausahaaan dimulai sejak usia dini. Karena masa anak-anak merupakan fase yang paling subur, paling panjang dan paling dominan untuk menanamkan norma-norma yang mapan. Anak-anak yang memiliki karakter kewirausahaan diharapkan mampu menyiapkan diri untuk mengejar cita-cita dan masa depannya.

Dalam proses pembentukan karakter kewirausahaan pada anak, peran orangtua sangatlah besar. Peran orang tua tersebut bermula dari harapan orang tua terhadap perkembangan anakanaknya. Harapan tersebut akan mengarahkan pola asuh orang tua terhadap anak. Selain dukungan dari orang tua, juga diperlukan dukungan dari lingkungan sekitar karena anak sangat mudah meniru dan menyerap informasi dari lingkungan.

b. Saran 
JAMALI - Volume. 01, Issue. 02, September 2019

Pengabdi berharap, kegiatan ini dapat terus berlanjut, baik pendampingan langsung kepada anak maupun kegiatan parenting untuk orang tua. Tokoh masyarakat di daerah pengabdian dapat bekerjasama dengan berbagai pihak untuk kelangsungan kegiatan tersebut, agar anak-anak di Dusun Tunggul Arum memiliki motivasi untuk mengejar cita-cita mereka dan menyiapkan masa depannya.

\section{Ucapan Terima Kasih}

Pengabdi mengucapkan terima kasih kepada:

1. Direktorat Penelitian dan Pengabdian Masyarakat (DPPM) Universitas Islam Indonesia yang telah memberikan dukungan dana dalam pelaksanaan kegiatan pengabdian ini.

2. Tokoh masyarakat di Dusun Tunggul Arum, Wonokerto-Turi atas kerjasama dan bantuan yang diberikan selama kegiatan pengabdian berlangsung.

\section{DAFTAR PUSTAKA}

Biro Pusat Statistik. 2017. Survey Program Penyediaan Air Minum dan Sanitasi Berbasis Masyarakat. Yogyakarta.

Buchari Alma. 2010. Kewirausahaan. Bandung: Alfabetha.

https://visitingjogja.com/12749/desa-wisata-tunggul-arum/

Jamaal Abdur Rahman. 2005. Tahapan Mendidik Anak, Teladan Rosulullah. Bandung: Irsyad Baitus Salam. 